\title{
Pyrazolones as a potential anticancer scaffold: Recent trends and future perspectives
}

\author{
Suman Adhikari ${ }^{1,2}$, Manjinder Singh ${ }^{2 *}$, Pratibha Sharma ${ }^{2}$, Sandeep Arora ${ }^{2}$ \\ ${ }^{1}$ Department of Pharmaceutical Chemistry, Netaji Subhas Chandra Bose Institute of Pharmacy, Chakdaha, India. \\ ${ }^{2}$ Chitkara College of Pharmacy, Chitkara University, Punjab, India.
}

\begin{tabular}{l}
\hline ARTICLE INFO \\
\hline Received on: 03/10/2019 \\
Accepted on: 27/05/2020 \\
Available online: $25 / 02 / 2021$
\end{tabular}

Key words:

Anticancer agent, pyrazolone, metal complex, cell line.

\begin{abstract}
Cancers are already placing an enormous load on the worldwide healthcare practice; so, anti-neoplastic compounds nowadays are most essential in cancer remedy. Nevertheless, the expanding resistance in drug profiles' appearance in recently available anticancer drugs has so far risen to a distressing level over past decades. Pyrazolone holds wideranging chemotherapeutic characteristics, including anticancer activity, and they inhabit a significant place in the novel drug development process. As per the literature, various hybridized pyrazolone moieties with different pharmacophores and pyrazolone metal complexes have anticancer activities with good potency. In recent years, pyrazolone hybrids and metal complexes were generated to study their anticancer properties. Out of these, some derivatives displayed promising strengths against the case of resistant and susceptible cell lines of cancer. This current review encloses the latest advances of pyrazolone hybrids including thiophene, aminomethylidenes, naphthoquinones, combretastatins, 2-substituted-4-(2-fluorophenoxy) pyridine, hydroxybenzo[a]phenazine, coumarin, dihydrobenzoxepine, cyclic peptide, cambinol derivatives of pyrazolone, and different metal complexes as a potential anticancer agent.
\end{abstract}

\section{INTRODUCTION}

Cancer is the second emerging disease that causes mortality throughout the world (Montana et al., 2019; Gao et al., 2019). Approximately 14 million of the latest cases, as well as deaths relating to nine million, arise annually (Jemal et al., 2011). In healthcare practice all over the world, a prodigious thrust is cancer. Recently, approved medicaments for cancer treatment are about 100 new agents, but none of them is specific in action and have too many side effects occurring during the treatment (Islam et al., 2011; Zhuang et al., 2019). Additionally, recently available antineoplastic agents have resistance against cancerous organs, making it necessary for the discovery of new drug candidates that are potent with regard to drug-resistant cancers (Mu et al., 2019; Singh et al., 2015). A diversity of scaffolds is extending in the development for this objective (Counihan et al.,

Abstract of this article was presented at CUDC consortium and Summer School Conference at Chitkara University, India.

"Corresponding Author

Manjinder Singh, Chitkara College of Pharmacy, Chitkara University,

Rajpura, India.E-mail: manjinder.singh@chitkara.edu.in

2018; Rashid et al., 2019), but it is not quite enough to regulate this universal threat.

Numerous heterocyclic derivatives of a five-membered nucleus containing two nitrogens (diazole) show important pharmacological activities and they represent a significant class of organic molecules (Katritzky et al., 1996). The chemistry of heterocyclic moiety containing compounds have an important position in the organic chemistry field. The pyrazole system has three carbons and two nitrogens in the five-membered cyclic ring that affords an important and versatile example in the innumerable natural and synthetic compounds. $1 H$-Pyrazole (1) is partially reduced to pyrazoline, which is represented by tautomers (2) and (3) (Weast, 1977).<smiles>c1cn[nH]c1</smiles>

(1)<smiles>C1=NNCC1</smiles>

(2)<smiles>C1=CNNC1</smiles>

(3) 
Pyrazolinones are oxo derivatives of pyrazolines. According to earlier literature, the typical technique was called "pyrazolone". However, a number of figure of tautomeric structures are feasible for pyrazolones, but according to the chemical abstracts, the names for these are 2-pyrazol-5-one (4), 3 pyrazol5-one (5), and 2-pyrazol-4-one (6). In many instances, there has been no particular recognition technique for a 2-pyrazolin-5-one or a 3-pyrazolin-5-one. The renowned German chemist, Ludwig Knorr, first revealed the synthesis of pyrazolone in the year 1983. The first time, 3-methyl-1-phenyl pyrazol-5-one (7) was prepared from a reaction of phenylhydrazine and ethyl acetoacetate (Wiley and Wiley, 1964).<smiles>O=C1CC=NN1</smiles>

(4)<smiles>O=C1C=NNC1</smiles>

(6)

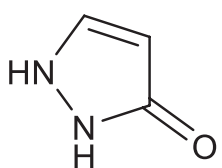

(5)

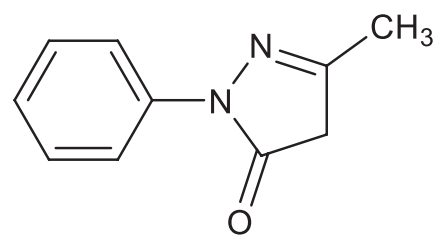

(7)

\section{Pyrazolones as an anticancer agent}

Pyrazolones are one among the oldest synthetic pharmaceuticals (Brogden, 1986; Brune, 1997) and its derivatives have an important position in the synthesis of many medicines. Numerous derivatives of pyrazolones, like antipyrine, aminopyrine, propyphenazone, and noraminopyrine methanesulfonate sodium, possess analgesic and antipyretic activities.

Pyrazolone derivatives express different pharmacological activities like antimicrobial (Akondi et al., 2016; Parmar et al., 2015), antitumor (Gouda et al., 2016), anti-inflammatory and analgesic (Mariappan et al., 2011), antifungal (Narayana Rao et al., 2014), anti-mycobacterial (Ahsan et al., 2012), anti-cholinergic and monoamnine oxidase inhibitors (Tok et al., 2019), antioxidants (Sivakumar et al., 2014), and antidiabetic (Yousuf et al., 2018). They are also used as ligands (Akcha et al., 2018) in complexes with catalytic activity. Some pyrazolones are also used as dyes (Rizk et al., 2017) for cotton, wool, and silk. Although pyrazole analogs have proven their clinical efficacy as different pharmacological agents, a few of them have been withdrawn from the market due to their side effects, like bone marrow depression, immunosuppression, etc. Thus, research on potential new drug candidates bearing pyrazole moiety with lesser side effects has fairly increased over the last few years. The long-term toxicity study with 4-methylpyrazole in rats found that pyrazole induced hyperplasia of the thyroid, hepatomegaly, atrophia of the testis, anemia, and depression of the bone marrow than the reference compound Douxorubicin (Gouhar et al., 2013).
As we all know, cancer is a complex disorder due to its complex pathophysiology. Numerous protein kinases, like BRAFV600E, epidermal growth factor receptor (EGFR), telomerase, reactive oxygen species (ROS) receptor tyrosine kinase, aurora-,A kinase etc., are involved in its pathology. The kinases can be involved in any of several steps of neoplastic development and progression. Cell division in mammalian cells is driven by protein kinases that regulate progression through various phases of the cell cycle. Cyclindependent kinases (CDKs) regulate cell cycle commitment, DNA synthesis, and the onset of mitosis. Kinases of the Aurora, Polo and NEK families participate in the centrosome cycle and modulate the spindle function. Additional kinases, such as Bub1, BubR1, and Mps1, regulate the spindle assembly checkpoint. It has been well established that the misregulation of cyclin-dependent kinases (CDKs) is one of the most frequent alterations in human cancer. Recent evidence indicates that mutations involving mitotic kinases are also linked to tumor development. These findings suggest novel strategies to use cell cycle kinases as targets for therapeutic intervention.

The vascular endothelial growth factor (VEGF) is the primary endothelial cell-specific angiogenic factor. The expression of these receptors occurs mainly in vascular endothelial cells, but has also been detected in melanoma cells lines and in some leukemic cell lines. The inhibition of kinases involved in tumor angiogenesis may also prove to be powerful antineoplastic therapy. CDK1 is generally considered to be a mitotic kinase, the other CDKs are believed to play a role in the early phases of cell division (interphase). In the past decade, different pyrazolecontaining compounds displayed as strong anticancer agents through the inhibition of (CDKs that are characteristics of a large protein kinases family, regulating eukaryotic cell cycle, and are extensively studied for their role in cancer (Ghorab et al., 2014). Aurora kinases, including Aurora A, B, and C, are key regulators of mammalian cell division. Aurora A localizes to centrosomes and spindle poles during mitosis, and its inhibition results in centrosome separation defects. VEGF is a mitogen that plays a crucial role in angiogenesis and lymphangiogenesis. It is involved in tumor survival through inducing tumor angiogenesis and by increasing chemoresistance through autocrine signaling. Additionally, the mitogen-activated protein kinase (MAPK) pathway regulates the gene expression, cellular growth, and survival. Abnormal MAPK signaling may lead to increased or uncontrolled cell proliferation and resistance to apoptosis. Research on the MAPK pathway has shown it to be important in some cancers. Pyrazole derivatives play an important role in antitumor agents because of their good inhibitory activity against BRAFV600E, EGFR, telomerase, ROS, receptor tyrosine kinase, and aurora-A kinase.

Various pyrazole derivatives induce apoptosis via the mitochondrial pathway, with a decrease in mitochondrial membrane potential and activation of the ROS via caspase- 3 and 7 activation, as well as via the external pathway with a significant increase in FAS-associated death domain protein expression.

Pyrazole derivatives are arrested in the G1 phase of the cell cycle via the downregulation of cyclin D2 and CDK2 (Fig. 1). 4-Aminoantipyrine is applied for the protection from oxidative stress and has a prophylactic effect on various cancer-involved diseases and is one of the better-honored pyrazolone derivative (Deshmukh et al., 2015). Different pyrazolone derivatives and their anticancer activities are described in the following sections. 


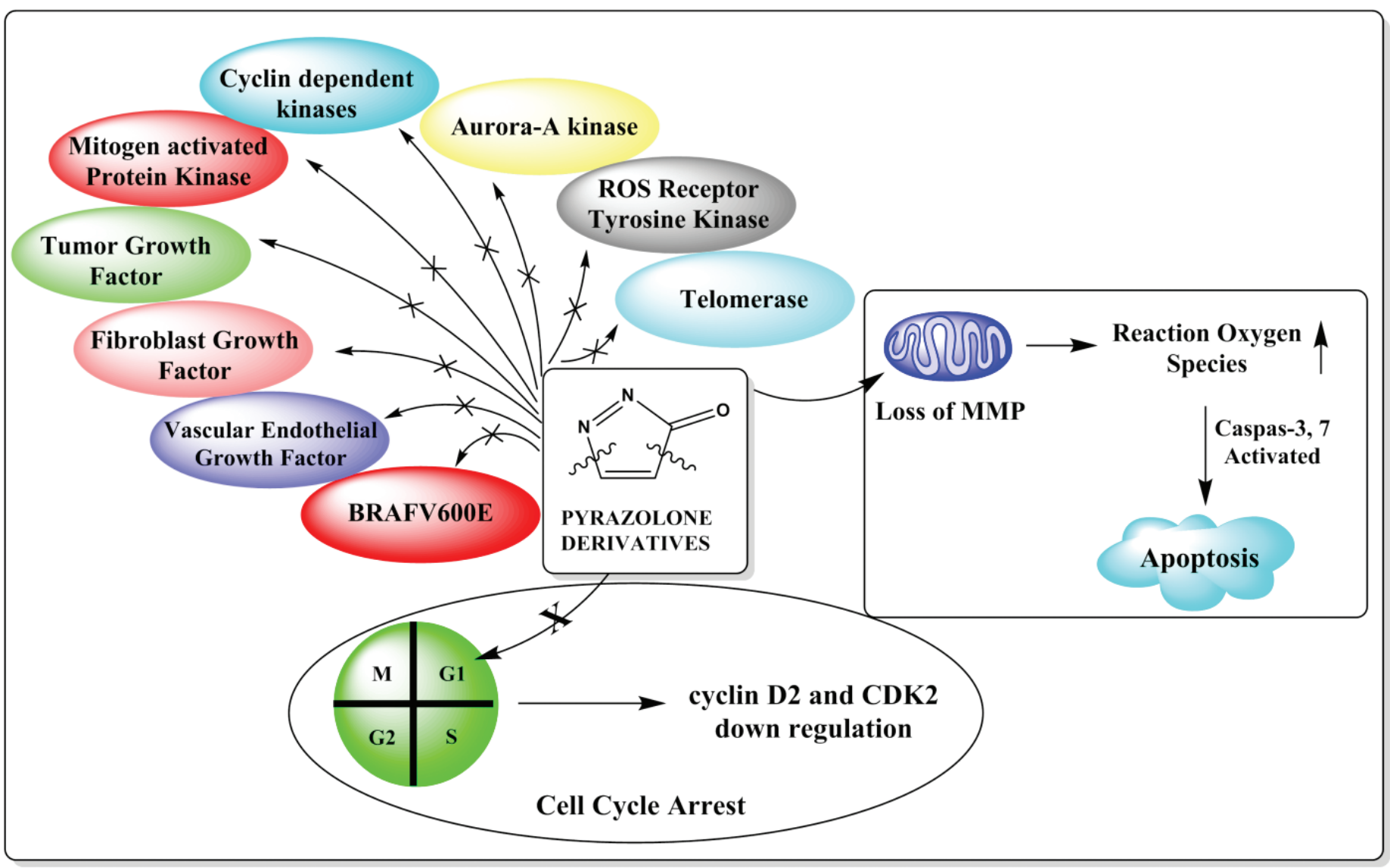

Figure 1. Targets and mechanism of action of pyrazolone moiety as an anticancer scaffold.

Thiophene-containing pyrazolone moieties as an anticancer agent

Novel classes of thiophene-containing pyrazolone derivatives (8 and 9) were prepared through the coupling reaction from diazonium salt. The compounds evaluated for antitumor activity by preparing several concentrations of tested derivatives in dimethyl sulfoxide (DMSO) (ED100, ED50, and ED25 $\mu \mathrm{g} / \mathrm{mL}$ in DMSO) and investigated for cytotoxic properties compared to standard agent 5-fluorouracil displayed good to moderate type of action, ranging from $100 \%$ to $22.8 \%$ of the dead tumor cells (Gouda et al., 2016).<smiles>[X]c1c(N/N=C2\C(=O)N([R])N=C2C)sc2c1CCCC2</smiles>

$\mathrm{X}=\mathrm{CONH}$, COOEt, $\mathrm{CN}$

(8)

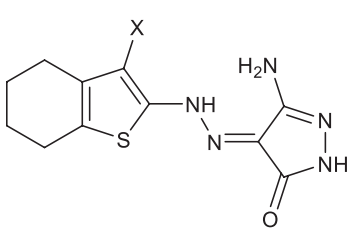

$\mathrm{X}=\mathrm{CONH}_{2}, \mathrm{COOEt}, \mathrm{CN}$

(9)
Aminomethylidene derivatives of pyrazolone as an anticancer agent

4-aminomethylidene derivatives (10), mainly 25, have been prepared and screened on cell lines for their anti-proliferative action. In-vitro antiproliferative activities were accompanied by an important apoptotic fraction of both cell lines. The major function displayed by these compounds was due to the inhibition of angiogenetic action and invasion mechanism (Marković et al., 2011).<smiles>[R]C1=NN([R7])C(=O)C1C=[R20]</smiles>

$\mathrm{R}=\mathrm{Ph}, \quad \mathrm{R}_{\mathbf{1}}=\mathrm{H}, \mathrm{Ph}$<smiles>[R7]#Cc1n[nH]cc1C(=O)OCC</smiles><smiles>Cc1cc[nH]n1</smiles><smiles>Cc1cc(C)[nH]n1</smiles>

(10)

Naphthaquinone derivatives of pyrazolone as an anticancer agent

A naphthaquinone compound, 2-((1,5-dimethyl-3-oxo-2phenyl-2,3-dihydro-1H-pyrazol-4-yl)amino)naphthalene-1,4-dione (DPDHN) (11), was derived by using a technique like ultrasound acceleration. This study is mainly based on molecular modeling, 
which was performed on the protein kinase CK2 to find out binding capacity on estrogen receptor for DPDHN $(-9.67 \mathrm{kcal} / \mathrm{mol})$ compared to tamoxifen $(10.37 \mathrm{kcal} / \mathrm{mol})$ and doxorubicin $(-7.3 \mathrm{kcal} /$ $\mathrm{mol})$ in Schrödinger software. The compound was further tested in in vitro studies for different cell lines (Kavitha Rani et al., 2018).<smiles>Cc1c(NC2=CC(=O)c3ccccc3C2=O)c(=O)n(-c2ccccc2)n1C</smiles>

(11)

\section{Pyrazolone-fused combretastatins as an anticancer agent}

A new series of compounds were synthesized which contained fused pyrazolone-containing combretastatins and its precursors were evaluated for cytotoxic and anti-tubulin potential. The fused pyrazolone-containing combretastatins derivatives (12a, $\mathbf{1 2 b}$, and 12c) have a strong action contrast to different cisplatinresistant cancer cells. The investigation based on molecular modeling studies also displayed that the accommodation capacity of the compounds (Burja et al., 2010).<smiles>COc1ccc(-c2[nH][nH]c(=O)c2-c2cc(OC)c(OC)c(OC)c2)cc1O</smiles><smiles>COc1ccc(-c2[nH][nH]c(=O)c2-c2cc(OC)c(OC)c(OC)c2)cc1F</smiles>

$12 a$
$12 b$<smiles>COc1ccc(-c2[nH][nH]c(=O)c2-c2cc(OC)c(OC)c(OC)c2)cc1</smiles>

$12 \mathrm{c}$

Pyrazolone scaffold-based pyridine nucleus as an anticancer agent

Pyrazolone scaffold-based pyridines analogs were developed for a novel potential anticancer agent with dual inhibition properties. In vitro cell-proliferation assay showed that most targeted compounds, especially (13), (14), and (15), had potential inhibition action on different cell lines. In vitro enzyme assay further showed that the most promising result was found in 15 (Gu et al., 2017).<smiles>CC1=C(C(=O)Nc2ccc(Oc3ccnc(C(=O)NCCCN4CCOCC4)c3)c(F)c2)C(=O)N(c2ccccc2)C1</smiles>

(13)<smiles>CN=Cn1cnnc1-c1cc(Oc2ccc(NC(=O)c3c(C)[nH]n(-c4ccccc4)c3=O)cc2F)ccn1</smiles>

(14)<smiles>Cc1nn(-c2ccccc2)c(=O)c(C(=O)Nc2ccc(Oc3ccnc(C4=NC=N4)c3)c(F)c2)c1C</smiles>

(15)

\section{Hydroxybenzo[a]phenazine-5-pyrazolone derivatives as an anticancer agent}

New groups of hydroxybenzo[a]phenazine-5pyrazolones were synthesized and screened for anticancer potentiality. The compound (16) showed the top level of activity by inhibiting cell growth. The compound (16) (BPP) was tested for the fragmentation of DNA, flow cytometry, and cytotoxicity studies against different cell lines. BPP loaded in a scaffold of nanofibrous has been checked for its cytotoxic activities against multiple cell lines. The nanofibrous scaffold containing PHBPCL-BPP showed apoptotic potential at 12, 24, and 48 hours by in vitro method on different cell lines of MCF-7, Hep-2, and NIH 3T3, respectively (Kandhasamy et al., 2017).<smiles>CC1=NN(c2ccccc2)C(=O)C1C(c1ccc(F)cc1)c1c(O)c2ccccc2c2nc3cc(C)ccc3nc12</smiles>

(16) 


\section{Coumarin-pyrazolone hybrids as an anticancer agent}

A series of novel synthesized coumarin-pyrazolones with excellent yield were screened for their anticancer activities at NCI60. The compound with methoxy on coumarin nucleus (17) showed marked action at $10^{-5} \mathrm{M}$ concentration with respect to different oncogenic cell lines (Kulkarni et al., 2018).<smiles>COc1ccc2oc(=O)cc(/C=C3\C(=O)N(c4ccccc4)N=C3C)c2c1</smiles>

(17)

\section{Dihydro benzoxepine-fused pyrazolones as an anticancer agent}

Cyclocondensation technique was used to prepare a new series of pyrazolones. Pyrazolones (18) were subjected to their oncogenic properties using conventional MTT cytotoxicity bioassay and doxorubicin as a standard. Compounds $18 \mathrm{i}^{\left(\mathrm{IC}_{50}\right.}$ : $84.29 \mu \mathrm{M})$ and $18 \mathrm{p}\left(\mathrm{IC}_{50}: 33 \mu \mathrm{M}\right)$ showed good to moderate anticancer activity on the A549 cell line. However, compounds $18 \mathrm{f}$ $\left(\mathrm{IC}_{50}: 67.55 \mu \mathrm{M}\right), 18$ hours $\left(\mathrm{IC}_{50}: 63.90 \mu \mathrm{M}\right), 18 \mathrm{k}\left(\mathrm{IC}_{50}: 97.00 \mu \mathrm{M}\right)$, and $18 \mathrm{r}\left(\mathrm{IC}_{50}: 78.17 \mu \mathrm{M}\right)$ displayed modest activity on DU-145 cell line (Saidachary et al., 2014).<smiles>[R]c1ccc2c(c1)C=C1C(=O)N(c3ccc([R])c([R2])c3[R3])N=C1CO2</smiles>

$$
\mathrm{R}=\mathrm{H}, \mathrm{R} 1=\mathrm{OCH}_{3}, \mathrm{R}_{2}=\mathrm{H}, \mathrm{R}_{4}=\mathrm{H}
$$

(18)

\section{Pyrazolones as VEGFR-2/KDR kinase inhibitors for anticancer activity}

A study was carried out on vascular endothelial growth factor receptors-2 (VEGFR-2)/kinase insert domain receptor (KDR) kinase, a new class considered to regulate angiogenesis. The inhibitors bearing heterocyclic (thiadiazole)-substituted pyrazolone (19) showed strong inhibition of VEGFR-2/KDR kinase with an increase in oral bioavailability achieved in rats up to $29 \%\left(8 \mathrm{~b}, \mathrm{IC}_{50}: 99 \mathrm{nM}\right)$. Glide XP docking approach supported the interaction on the kinase insert domain receptor, particularly at the hinge region by the pyrazolones (Modi and Kulkarni, 2019; Metwally et al., 2019; Tripathy et al., 2007).<smiles>Cc1nnsc1C1=NNC(=O)/C1=C\c1cc2cc(F)ccc2n1C</smiles>

(19)

\section{Anaplastic lymphoma kinase inhibitor based on pyrazolone nucleus}

The identification of the methyl thiazole nucleus containing lead was confirmed by cross-reactivity with anaplastic lymphoma receptor tyrosine kinase found in different cancer variants, like anaplastic large cell lymphoma and nonsmall-cell lung carcinoma. A lead-bearing methyl-thiadiazole of pyrazolone-based kinase inhibitor series developed as strong anaplastic lymphoma receptor tyrosine kinase inhibitors. Compound (20) displayed the strongest activity on anaplastic lymphoma receptor tyrosine kinase with ( $\mathrm{IC}_{50}$ value: $23 \mathrm{nM}$ ). But compound (21) displayed the overall best result with a good pharmacokinetic profile in rats (Tripathy et al., 2011).

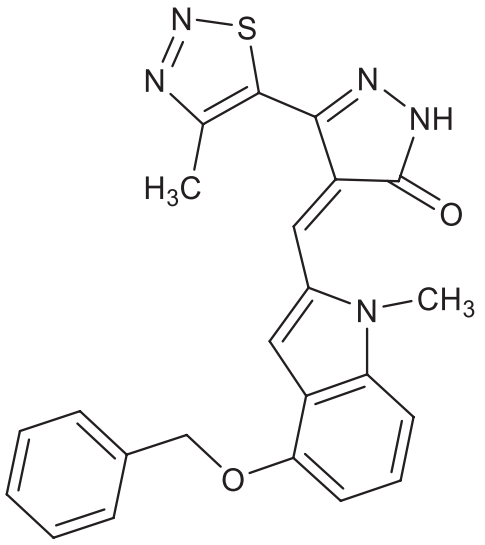

(20)<smiles>Cn1c(/C=C2\C(=O)NN=C2c2nccs2)cc2c(OCc3ccccc3)cccc21</smiles>

(21)
Pyrazolone ring containing cyclic peptide as an antitumor agent

A mudflat-derived Streptomyces strain was used to isolate a new cyclic peptide (WS9326H). WS9326H (22) has the acyclic heptapeptide, which is characterized by the spectrometry-based analysis. The anti-angiogenic property of WS9326H was measured by the formation of a capillary tube. A significant pharmacological property (antiangiogenic) displayed at a concentration of $20 \mu \mathrm{M}$ without cytotoxicity (Bae et al., 2018). 


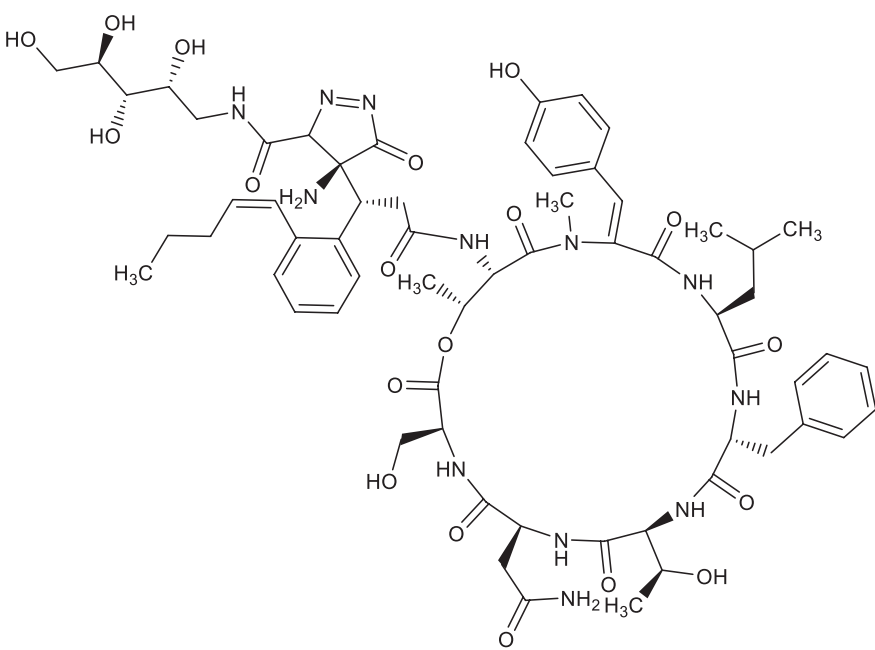

(22)

\section{Pyrazolone-cambinol derivatives as sirtuin inhibitor for anticancer activity}

A series of pyrazolone-cambinol analogs were studied as a sirtuin inhibitor based on SIRT-Glo assay. The most selective compounds (23) and (24) showed fivefold and sevenfold greater activity in SIRT1 over SIRT2 (silent mating type information regulation $1 \& 2$ ), respectively (Mahajan et al., 2014).

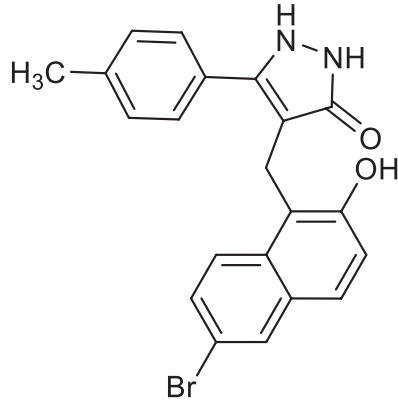

(23)

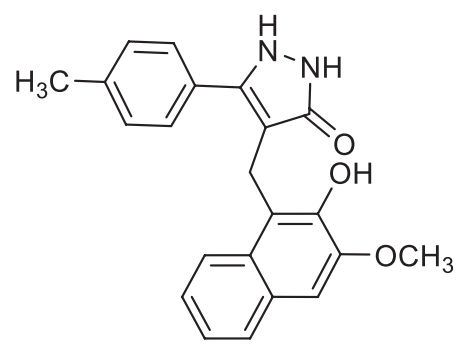

(24)

\section{Pyrazolone metal complexes as an anticancer agent}

The synthesis of the cobalt (II) metal complex of 5-pyrazolone ligand (25) and its interaction measured by using cyclic voltammetry and electronic spectrometry with fish sperm DNA was carried out. The identification of intercalation properties was carried out by the strength and mode of interaction. The complex and its ligand were investigated to find out cytotoxic or cytostatic properties on human carcinomic cell lines (like PC-3 and HT-29) (Akcha et al., 2018; Tüzün, 2019).

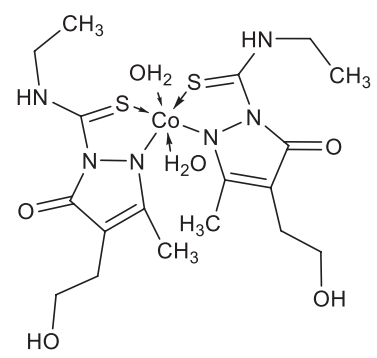

(25)

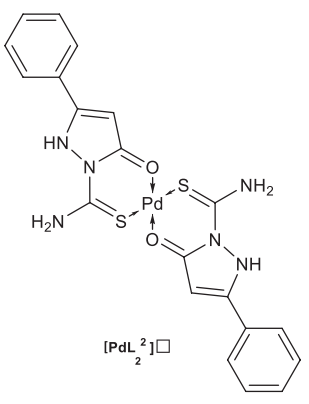

(26)
Novel complexes of palladium (II) and platinum (II) [ML2] were prepared from $\beta$-ketoester thiosemicarbazones by reaction with $\mathrm{K}_{2} \mathrm{PdCl}_{4}$ or $\mathrm{K}_{2} \mathrm{PtCl}_{4}$ or lead acetate. Seven metal complexes were determined by diffraction techniques based on X-rays. The palladium metal complex (26) exhibited pharmacological properties as same as the cisplatin on the cancer cell line (A2780). Nearly 16 times stronger action against cell lines like A2780 cis R was compared to cis-dichlorodiammineplatinum (DDP) (Casas et al., 2008).

Manganese complexes (27) and (28) were synthesized and characterized, and its binding interaction with DNA of herring sperm revealed that they might be intercalating with the DNA. The inhibitory effects were measured by cell population growth in different human cancer cell lines. MTT assay also indicated that the complex (27) has a stronger inhibitory activity than that of complex (28) (Li et al., 2015).

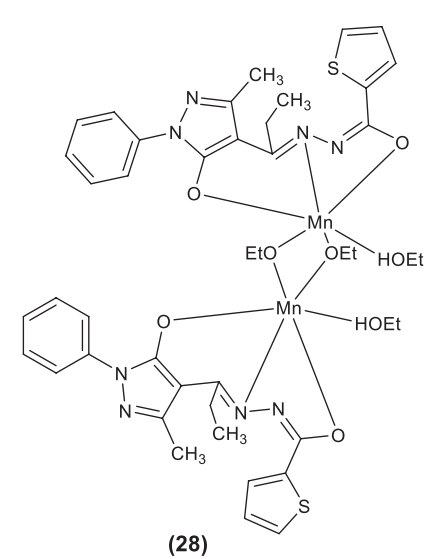

(28)

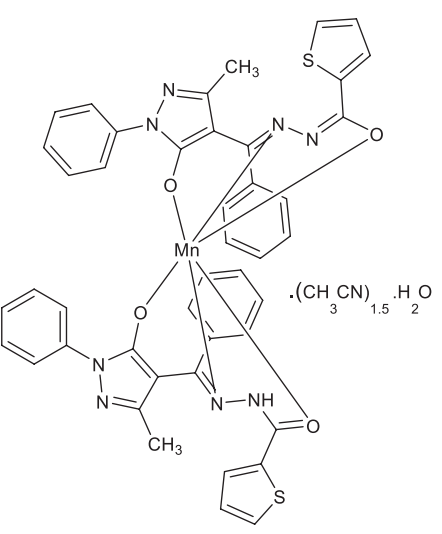

(27)
Synthesis and characterization of organometallic platinum (II) derivatives (29) were done by different spectroscopic also physicochemical techniques. The synthesized derivatives were further investigated for cytotoxic properties. The synthesized compounds were investigated for interaction and cleavage properties on DNA against herring sperm DNA (Lunagariya et al., 2018).

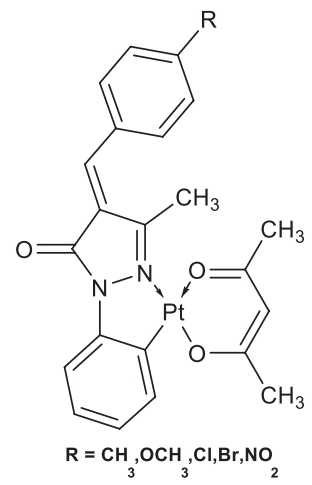

(29)

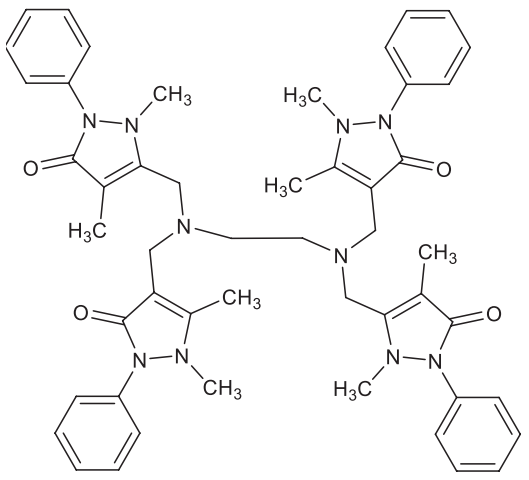

(30)
The copper complex consisting of ligand (30) and containing a mannich base was prepared and further determined. Both the pyrazolone-containing ligand and their complexes were tested against breast cancer, glioblastoma multiforme, lung carcinoma hepatoma, and nontumor human cell lines. The copper complex was found to decrease in viable tumor cells in different cell lines compared to ligand (30) (Mosoarca et al., 2011). 
New isolated and deliberately characterized metal complexes of vanadium (II), manganese (II), cobalt (II), nickel (II), and copper (II) containing pyrazolones from ligand (31) were studied. AutoDock tools in molecular docking were utilized to dock the complexes in protein receptors for cancer of liver, colon, and prostates. The calculated energies of complexation displayed that pyrazolone compounds have the best antitumor activity against variable carcinoma. $\mathrm{IC}_{50}$ values $(0.061$ and $0.389 \mu \mathrm{g} / \mathrm{ml}$, respectively) represented that $\mathrm{Cu}$ (II) complex showed excellent activitiy against human liver cancer cell line (HEPG2) and PC3 cell lines in contrast to doxorubicin (standard), but Mn (II) complex $\left(\mathrm{IC}_{50}=0.2213 \mu \mathrm{g} / \mathrm{ml}\right)$ showed a higher relative influence against HCT116 (colon carcinoma) cell line (Saad et al., 2016).

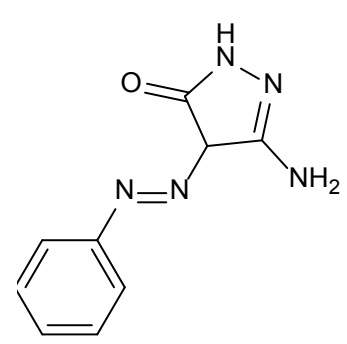

(31)

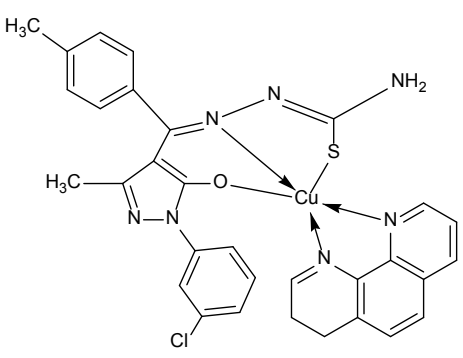

(32)
The first time a new [Cu(TMCPMP-TS)(Phen)] (32) complex was prepared and its intercalation action were shown by binding through interaction with calf thymus DNA. The complex was compared to the free ligands in bovine serum albumin for a strong protein-binding capacity. The anticancer activity was studied on A549 cell line when it was exposed to the complex by oxidative mechanism-based mitochondrial damage. The complex induced cell death by ending the S and G2 or M phases of the cell cycle after 1 day of treatment. The results indicated that $\mathrm{Cu}$ (TMCPMPTS) (Phen) holds ample merit in the development of anticancer agents (Vyas et al., 2013).

A novel group of copper (II) metal complexes, like copper complex along with phenyl (33), copper complex along with biphenyl (34), and copper metal complex [binary type] (35), were prepared and determined using structure-based, analyticalbased, and spectroscopic techniques. The DNA interaction was detected using titrimetric methods which displayed an interaction with calf thymus DNA by compounds that were caused by the intercalation method. The substantial cytotoxicity properties are shown when these three complexes were tested on A549 and H9C2 cell lines (Vyas et al., 2014).

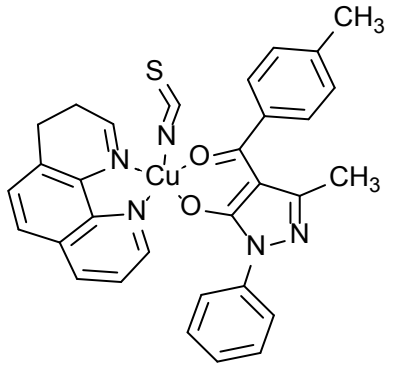

(33)

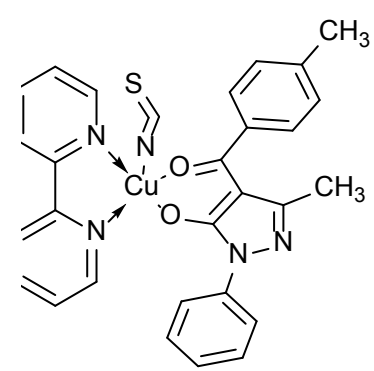

(34)

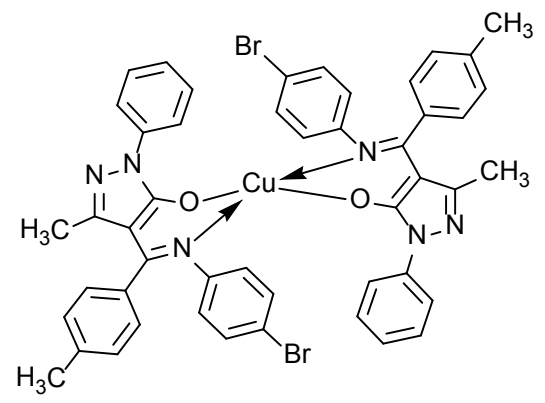

(35)

Pyrazolone nucleus-contained copper (II) complex (36) was prepared and then identified using analytical techniques. The copper (II) complex had strong anticancer properties compared to pyrazolone containing ligand. The analysis of the crystallographic structure revealed that it resulted from the formation of the doublenuclear complex by coordination with $\mathrm{Cu}$ atom. The ovarian carcinoma cell line 3 and Hep-G2 cancer cells were used to test the antitumor properties, which have lethal concentration $50 \%\left(\mathrm{IC}_{50}\right)$ values of $17.6 \mu \mathrm{g} / \mathrm{ml}$ and $15.0 \mu \mathrm{g} / \mathrm{ml}$ due to the coordination effect and improvement (Zhang et al., 2010).

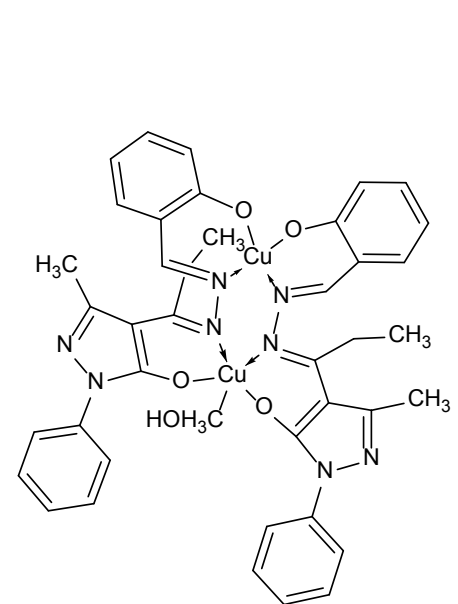

(36)

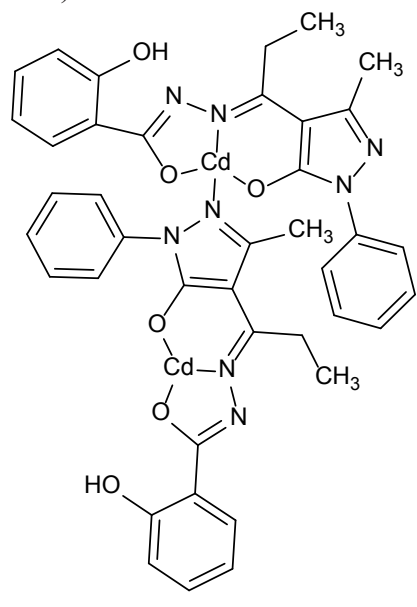

(37)
A pyrazolone nucleus-contained derivative (37) was tested on Eca-109 cancerous cell line with a dose-related fashion which generated an apoptotic action due to elevation in ROS formation along with mitochondria-mediated pathway based on the caspase-dependent pathway. The $\mathrm{IC}_{50}$ value was found to be $29.86 \mu \mathrm{M}$, higher than that of DDP and also had an inhibitory effect on the normal human gastric epithelial cell line cell proliferation. Finally, the $\mathrm{IC}_{50}$ value of Cd-PMPP-SAL was suggested as a potential anticancer candidate (Zhao et al., 2015).

The synthesis of three ligands containing pyrazolone nucleus-based enamine derivatives was carried out by the reaction of different compounds. The complexes of zinc with ligand 1 (38), cobalt with ligand 2 (39), copper with ligand 3 (40), zinc with ligand 3 (41), and cadmium with ligand 3 (42) were also prepared, which were elucidated using different spectroscopic and thermal analyses. The anticancer activities of all five complexes have been investigated and their results suggested that complexes $\mathbf{3 8}$ and 
39 can effectively inhibit cell proliferation in MDA-MB-231 cell lines by decreasing viabilities at a $60 \mu \mathrm{M}$ concentration to almost 2\% using by an MTT assay (Zong et al., 2018).

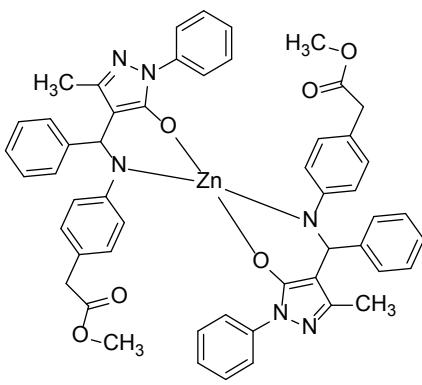

(38)

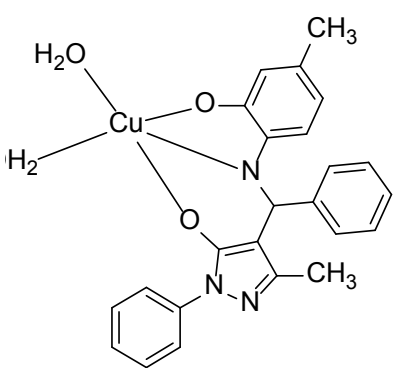

(40)

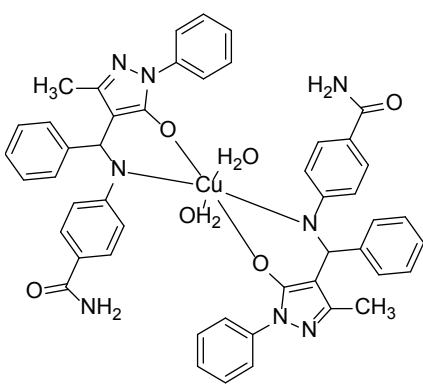

(39)

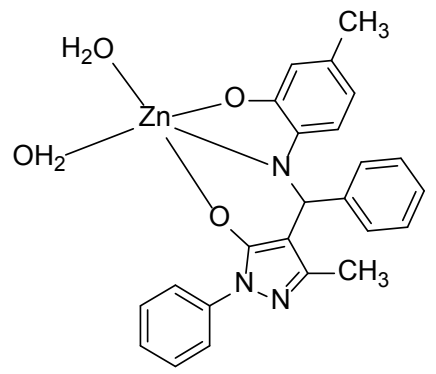

(41)<smiles>Cc1ccc2c(c1)O[C@H](O)[C@@H](c1ccccc1)c1c(C)nn(-c3ccccc3)c1O2</smiles>

(42)
A ligand containing pyrazol-5-one moiety and its nickel (II) (43), palladium (II) (44), and platinum (II) (45) complexes was derived by a chemical reaction. Furthermore, their biological activities were also evaluated using MTT assay against different HePG-2, HCT-116, PC-3, and MCF-7 human cancerous cell lines. The ligand displayed potent cytotoxic activity in contrast to 5-fluorouracil (standard). The order of activity was palladium complex $>$ nickel complex $>$ platinum complex (Bakr et al., 2017).

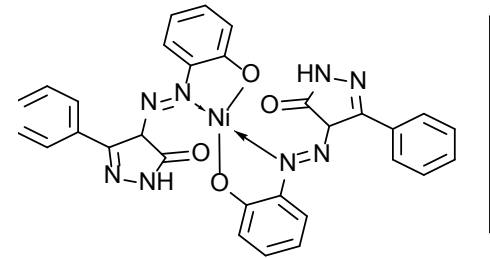

(43)

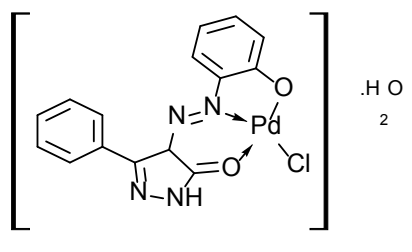

(44)

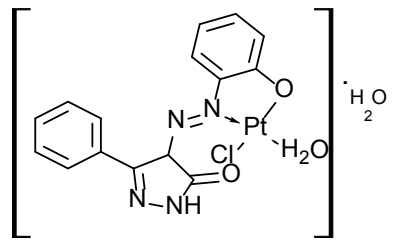

(45)

New nanosized manganese (II), cobalt (II), chromium (III), and copper (II) metal complexes were prepared by precipitation method using pyrazolone-containing benzoic acid ligand, (46). The activity of HL and their complexes were identified by neoplastic activity in HEPG2 cell line (human hepatocellular carcinoma) utilizing the reference drug (Doxorubicin, $\mathrm{IC}_{50}=4.73$ ). A weak cytotoxic activity of HL and its manganese (II), cobalt (II), chromium (III), and copper (II) metal complexes $\left(\mathrm{IC}_{50}=15.3\right.$, $174,52.4,102,23.5 \mu \mathrm{g} / \mathrm{ml}$ ) was exhibited in HEPG2 (human liver carcinoma) cell line (Gaber et al., 2018).<smiles>O=C(O)c1ccccc1NNC1C(=O)N(c2ccccc2)N=C1c1ccccc1</smiles>

(46)

New Pt (II) metal complexes were synthesized using 4-acyl-5-pyrazolones and in vitro biological assays were performed on cancerous cell lines like HeLa and MCF-7 (platinum-resistant) using cisplatin as the reference standard. Trans-[ $\mathrm{PtCl}_{2}(\mathrm{DMSO})$ $(\mathrm{HQPh})$ (47) complex showed greater cytotoxic activity on HeLa cells than that of $c i s-\left[\mathrm{PtCl}_{2}(\mathrm{DMSO})(\mathrm{HQPh})\right](48)$ complex (De Pascali et al., 2014).<smiles>CC1C(C(=O)c2ccccc2)=C(O)N(c2ccccc2)N1[P+](Cl)(Cl)S(C)(=O)=O</smiles>

(47)<smiles>CC1C(C(=O)c2ccccc2)=C(O)N(c2ccccc2)N1[P+](Cl)(Cl)S(C)(=O)=O</smiles>

(48)
Ruthenium (II) compounds (49) were synthesized to performed anti-tumor activities on the different oncogenic cell lines. Ruthenium derivative with naphthoyl (R) and p-cymene (arene) substitutions exhibited the strongest action as antitumor agent systematically and also intercalation with DNA was feasible with naphthoyl derivative in docking studies (Caruso et al., 2014). 
<smiles></smiles>

(49) arene

1. $\mathbf{R}=\mathrm{Me}$, arene = p-cymene

2. $\mathbf{R}=\mathrm{Ph}$, arene = p-cymene

3. $\mathbf{R}=\mathrm{Naph}$, arene = p-cymene

4. $\mathbf{R}=\mathrm{Me}$, arene = benzene

5. $\mathbf{R}=\mathrm{Me}$, arene = hexamethylbenzene

6. $\mathrm{R}=\mathrm{Ph}$, arene = hexamethylbenzene

Ruthenium (II) metal complexes with aromatic nucleus were prepared from ligands ( $\beta$-keto amine consisting of pyrazolone nucleus) to measure the effect of aromatic substituents with anticancer properties in respect to A2780 and A2780cisR oncogenic cell lines using MTT cytotoxicity bioassay. Complex (50) displayed significantly more cytotoxic properties in the A2780cisR cell line compared to cisplatin. But complexes (51) and (52) displayed likely greater action than cisplatin in cell lines with cytotoxic resistance (Pettinari et al., 2014).

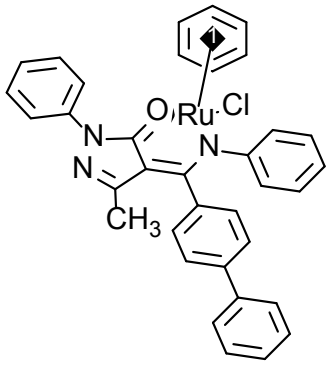

(50)

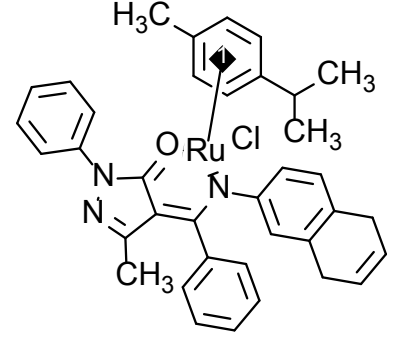

(51)

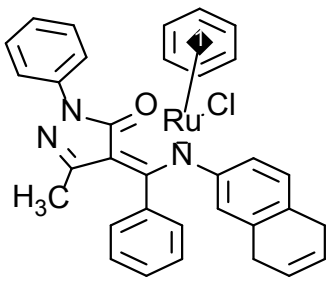

(52)

The study was carried out based on the identification of Pro-apoptotic BCL2 Associated X (BAX)-activating derivatives having novel potential anticancer activity. The pyrazolone derivative (53) was tested to develop anticancer properties of direct BAX activators compared to venom in the future (Stornaiuolo et al., 2015).<smiles>COc1ccccc1N/N=C1\C(=O)N(c2cc(O)cc(-c3ccc(N(C)C)cc3)c2)N=C1C</smiles>

Three pyrazolone-based hydrazone ligands were synthesized, then they were elucidated using nuclear magnetic resonance spectroscopy by using a solution and solid-state method. Six derivatives of arene-ruthenium (II) (54) were further prepared and the cytotoxicity properties on adenocarcinoma cell lines of human breast and also on the noncancerous breast cell lines of human were evaluated, which were compared with the pyrazolone-based hydrazone ligand and standard [cisplatin] (Pettinari et al., 2018).

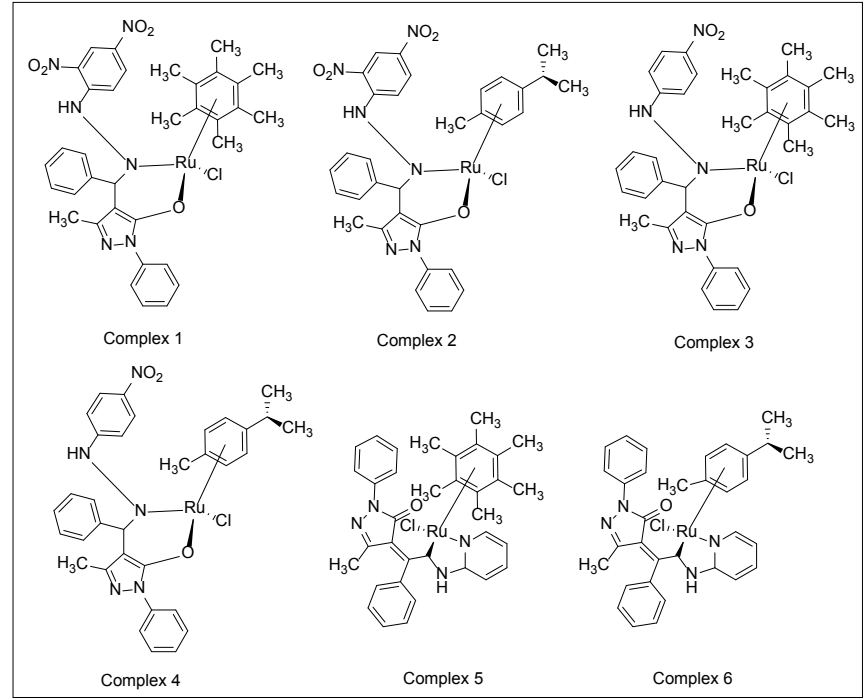

(54)

Classes of unique cobalt (II), copper (II), nickel (II), and zinc (II) metal complexes (55) were prepared from Schiff bases containing pyrazolones. DNA-binding properties revealed that the complexes association to DNA of calf thymus through an interactive approach. Cyclic voltammetry, viscosity, and absorption spectra (electronic) measurements were used to identify different metal (II) chlorides. The complex of $\mathbf{C u}$ (II) had more ability of intercalation in contrast to other complexes that signified by the binding constant $\left(\mathrm{K}_{\mathrm{b}}=8.6 \times 104 \mathrm{M}^{-1}\right)$ values (Paulpandiyan et al., 2016).

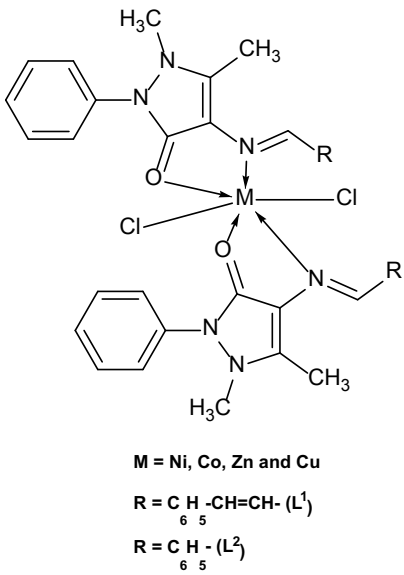

(55)

\section{Pyrazolones derivatives undergoing clinical studies}

Edaravone (3-methyl-1-phenyl-2-pyrazolin-5-one, 56) exerts a therapeutic effect on radiation-induced temporal lobe necrosis (TLN), the most serious sequelae of radiotherapy, and 
impairs the patients' quality of life profoundly. The randomized controlled trial was carried out to evaluate the effect of free radical scavenger, edaravone, on radiation-induced TLN in patients with nasopharyngeal carcinoma after radiotherapy. The trial is registered at Clinicaltrials.gov Identifier: NCT01865201 between 2009 and 2012, with 154 patients. The administration of edaravone, in adjunct to steroid regimen, might provide a better outcome in patients with radiation-induced brain necrosis (Tang et al., 2014).

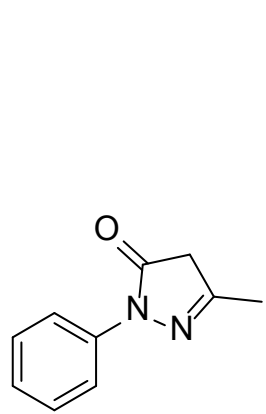

(56)

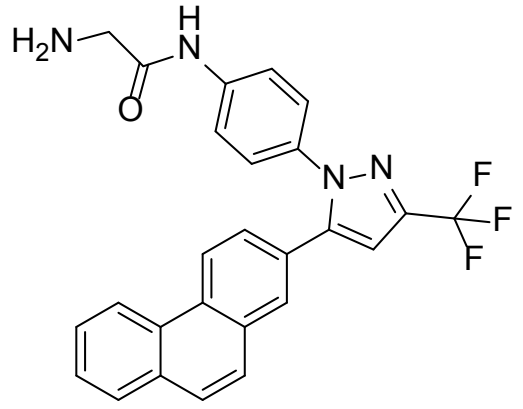

(57)
AR-12, (2-Amino-N-[4-[5-(2 Phenanthrenyl)-3(Trifluoromethyl)-1H-pyrazol-1-yl]Phenyl]-Acetamide, 57) was a single agent undergoing open-label, phase 1, dose-escalation study in adult patients with advanced or recurrent solid tumors or lymphoma. The primary objective of this study in adults with advanced or recurrent solid tumors or lymphoma is to evaluate the safety and tolerability of AR-12.

AMG 337 (58), another pyrazole derivative, showed antitumor activity in MET-amplified G/GEJ/E adenocarcinoma but not in MET-amplified non-small-cell lung cancer. MET gene (MET Proto-Oncogene, Receptor Tyrosine Kinase) amplification is associated with poor prognosis in gastric/gastroesophageal junction/ esophageal (G/GEJ/E) cancers. A multicenter phase II study of AMG 337 in patients with MET-amplified gastric/gastroesophageal junction/ esophageal adenocarcinoma and other met-amplified solid tumors was conducted recently and found that AMG 337 showed antitumor activity in MET-amplified G/GEJ/E adenocarcinoma, but not in MET-amplified non-small-cell lung cancer (Cutsem et al., 2019).

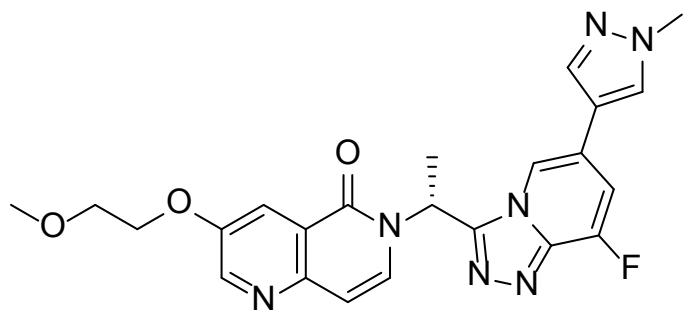

(58)

\section{CONCLUSION}

Cancer management has made considerable improvements after years of anticancer research and there is an appreciable contribution in the identification and development of many Pyrazolone derivatives for the management of carious cancers. Pyrazolone holds wide-ranging chemotherapeutic characteristics, including anticancer activity, and they inhabit a significant place in the novel drug development process. Hybridized pyrazolone moiety with different pharmacophores and pyrazolone metal complexes has the capacity to expand the anticancer activity. In recent years, pyrazolone hybrids and metal complexes were generated to study their anticancer properties. Out of these, some derivatives displayed promising strengths against the case of resistant and susceptible cell lines of cancer. This current review encloses the latest advances of pyrazolone hybrids, including thiophene, aminomethylidenes , naphthoquinones, combretastatins, 2-substituted-4-(2-fluorophenoxy) pyridine, hydroxybenzo[a]phenazine, coumarin, dihydrobenzoxepine, cyclic peptide, cambinol derivatives of pyrazolone and different metal complexes as a potential anticancer agents.

\section{AUTHOR CONTRIBUTIONS}

All authors made substantial contributions to conception and design, acquisition of data, or analysis and interpretation of data; took part in drafting the article or revising it critically for important intellectual content; agreed to submit to the current journal; gave final approval of the version to be published; and agree to be accountable for all aspects of the work.

\section{FUNDING}

There is no funding to report.

\section{CONFLICTS OF INTEREST}

The authors report no financial or any other conflicts of interest in this work.

\section{ETHICAL APPROVALS}

Not applicable.

\section{PUBLISHER'S NOTE}

This journal remains neutral with regard to jurisdictional claims in published institutional affiliation.

\section{REFERENCES}

Ahsan MJ, Samy JG, Jain CB, Dutt KR, Khalilullah H, Nomani MS. Discovery of novel anti-tubercular 1,5-dimethyl-2-phenyl-4-([5(arylamino)-1,3,4-oxadiazol-2-yl]methylamino)-1,2-dihydro-3H-pyrazol3-one analogues. Bioorg Med Chem Lett, 2012; 22:969-72.

Akcha S, Gómez-Ruiz S, Kellou-Tairi S, Lezama L, Pérez FB, Benali-Baitich O. Synthesis, characterization, solution equilibria, DFT study, DNA binding affinity and cytotoxic properties of a cobalt(II) complex with a 5-pyrazolone ligand. Inorg Chim Acta, 2018; 482: $738-48$.

Akondi AM, Kantam ML, Trivedi R, Bharatam J, Vemulapalli $\mathrm{SPB}$, Bhargava SK, Prakasham RS. Ce/SiO2 composite as an efficient catalyst for the multicomponent one-pot synthesis of substituted pyrazolones in aqueous media and their antimicrobial activities. J Mol Catal A Chem, 2016; 411:325-36.

Bae M, Oh J, Bae ES, Oh J, Hur J, Suh YG, Lee SK, Shin J, Oh DC. WS9326H, an antiangiogenic pyrazolone-bearing peptide from an intertidal mudflat actinomycete. Org Lett, 2018; 20:1999-02.

Bakr EA, Al-Hefnawy GB, Awad MK, Abd-Elatty HH, Youssef MS. New Ni(II), Pd(II) and Pt(II) complexes coordinated to azo pyrazolone ligand with a potent anti-tumor activity: synthesis, characterization, DFT and DNA cleavage studies. Appl Organomet Chem, 2017; 32:4104-7.

Brogden RN. Pyrazolone derivatives. Drugs, 1986; 32:60-70. 

1997; 1:33-40

Brune K. The early history of non-opioid analgesics. Acute Pain,

Burja B, Čimbora-Zovko T, Tomić S, Jelušić T, Kočevar M, Polanc S, Osmak M. Pyrazolone-fused combretastatins and their precursors: synthesis, cytotoxicity, antitubulin activity and molecular modeling studies. Bioorg Med Chem, 2010; 18:2375-87.

Caruso F, Monti E, Matthews J, Rossi M, Gariboldi MB, Pettinari C, Pettinari R, Marchetti F. Synthesis, characterization, and antitumor activity of water-soluble (Arene)ruthenium(II) derivatives of 1,3-Dimethyl-4-acylpyrazolon-5-ato ligands. first example of $\mathrm{Ru}$ (arene) (ligand) antitumor species involving simultaneous $\mathrm{Ru}-\mathrm{N} 7$ (guanine) bonding and ligand intercalation to DNA. Inorg Chem, 2014; 53:3668-77.

Casas JS, Castellano EE, Ellena J, García-Tasende MS, PérezParallé ML, Sánchez A, Sánchez-González Á, Sordo J, Touceda Á. New $\mathrm{Pd}(\mathrm{II})$ and $\mathrm{Pt}(\mathrm{II})$ complexes with $\mathrm{N}$, S-chelated pyrazolonate ligands: molecular and supramolecular structure and preliminary study of their in vitro antitumoral activity. J Inorg Biochem, 2008; 102:33-45.

Counihan JL, Grossman EA, Nomura DK. Cancer metabolism: current understanding and therapies. Chem Rev, 2018; 118:6893-23.

Cutsem, EV, Karaszewska, B, Kang, YK, Chung, HV, Shankaran, V, Siena, S, Go, NF, Yang, H, Schupp, M, Cunningham, D. A multicenter phase II study of AMG 337 in patients with MET-amplified gastric/gastroesophageal junction/esophageal adenocarcinoma and other MET-amplified solid tumors. Clin Cancer Res, 2019; 25:1445-56.

De Pascali SA, Migoni D, Monari M, Pettinari C, Marchetti F, Muscella A, Fanizzi FP. Synthesis, crystal structure, and biological study of PtII complexes with 4-Acyl-5-pyrazolones. Eur J Inorg Chem, 2014; 7:1249-59.

Deshmukh P, Soni PK, Kankoriya A, Halve AK, Dixit R. 4-Aminoantipyrine: a significant tool for the synthesis of biologically active schiff bases and metal complexes. Int J Pharma Sci Rev Res, 2015; $34: 162-70$.

Gaber M, Khedr AM, Mansour MA, Elsharkawy M. Nanosynthesis, characterization, modeling and molecular docking analysis of $\mathrm{Mn}$ (II), $\mathrm{Co}$ (II), $\mathrm{Cr}$ (III) and $\mathrm{Cu}$ (II) complexes with azo pyrazolone ligand as new favourable antimicrobial and antitumor agents. Appl Organomet Chem, 2018; 1:4606-8.

Gao F, Zhang X, Wang TF, Xiao JQ. Quinolone hybrids and their anti-cancer activities: an overview. Eur J Med Chem, 2019; 165:59-79.

Ghorab MM, El-Gazzar MG, Alsaid MS. Synthesis, characterization and anti-breast cancer activity of new 4-aminoantipyrinebased heterocycles. Int J Mol Sci, 2014; 15:7539-53.

Gouda MA, Eldien HF, Girges MM, Berghot MA. Synthesis and antitumor evaluation of thiophene based azo dyes incorporating pyrazolone moiety. J Saudi Chem Soc, 2016; 20:151-57.

Gouhar, RS, Fathalla OA, Abd El-Karim SS. Synthesis and anticancer screening of some novel substituted pyrazole derivatives. Der Pharma Chem, 2013; 5:225-33

Gu W, Dai Y, Qiang H, Shi W, Liao C, Zhao F, Huang W. Discovery of novel 2-substituted-4-(2-fluorophenoxy) pyridine derivatives possessing pyrazolone and triazole moieties as dual c-Met/VEGFR-2 receptor tyrosine kinase inhibitors. Bioorg Chem, 2017; 72:116-22.

Islam MS, Wang CY, Zheng JY, Paudyal N, Zhu YL, Sun HX. The potential role of tubeimosides in cancer prevention and treatment. Eur J Med Chem, 2019; 162:109-21.

Jemal A, Bray F, Center MM, Ferlay J, Ward E, Forman D. Global cancer statistics. CA Tumor J Clin, 2011; 61:69-90.

Kandhasamy S, Ramanathan G, Muthukumar T, Thyagarajan S, Umamaheshwari N, Santhanakrishnan VP, Sivagnanam UT, Perumal PT. Nanofibrous matrixes with biologically active hydroxybenzophenazine pyrazolone compound for cancer theranostics. Mat Sci Eng, 2017; 74:70-5.

Katritzky AR, Rees CW, Scriven EF. Comprehensive heterocyclic chemistry II. 5th edition, Pergamon, Oxford, UK, pp 301-9, 1996.

Kavitha Rani PR, Sheena Mary Y, Fernandez A, Anu Priya S, Shyma Mary Y, Thomas R. Single-crystal XRD, DFT investigations and molecular docking study of 2-((1,5-dimethyl-3-oxo-2-phenyl-2,3-dihydro$1 H$-pyrazol-4-yl)amino)naphthalene-1,4-dione as a potential anti-cancer lead molecule. Comput Biol Chem, 2018, 78:153-64.
Kulkarni RC, Madar JM, Shastri SL, Shaikh F, Naik NS, Chougale RB, Shastri LA, Joshi SD, Dixit SR, Sunagar VA. Green synthesis of coumarin-pyrazolone hybrids: in vitro anticancer and anti-inflammatory activities and their computational study on COX-2 enzyme. Chem Data Collect, 2018; 17:497-06.

Li Y, Zhao J, He CC, Zhang L, Sun SR, Xu GC. Synthesis, crystal structure and biological activity of two Mn complexes with 4-acyl pyrazolone derivatives. J Inorg Biochem, 2015; 150:28-7.

Lunagariya MV, Thakor KP, Kanthecha DN, Patel MN. Synthesis, characterization and biological applications of substituted pyrazolone corebased platinum(II) organometallic compounds. J Organomet Chem, 2018 854:49-3.

Mahajan SS, Scian M, Sripathy S, Posakony J, Lao U, Loe TK, Leko V, Thalhofer A, Schuler AD, Bedalov A, Simon JA. Development of pyrazolone and isoxazol-5-one cambinol analogues as sirtuin inhibitors. J Med Chem, 2014; 57:3283-94.

Mariappan G, Saha BP, Sutharson L, Singh A, Garg S, Pandey L, Kumar D. Analgesic, anti-inflammatory, antipyretic and toxicological evaluation of some newer 3-methyl pyrazolone derivatives. Saudi Pharm J, 2011; 19:115-22.

Marković V, Erić S, Stanojković T, Gligorijević N, Aranđelović S, Todorović N, Trifunović S, Manojlović N, Jelić R, Joksović MD. Antiproliferative activity and QSAR studies of a series of new 4-aminomethylidene derivatives of some pyrazol-5-ones. Bioorg Med Chem Lett, 2011; 21:4416-21.

Metwally, NH, Mohamed, MS, Ragb, EA. Design, synthesis, anticancer evaluation, molecular docking and cell cycle analysis of 3-methyl-4,7-dihydropyrazolo[1,5-a]pyrimidine derivatives as potent histone lysine demethylases (KDM) inhibitors and apoptosis inducers. Bioorg Chem, 2019; 88:1029-32.

Modi JS, Kulkarni MV. Vascular endothelial growth factor receptor (VEGFR-2)/KDR inhibitors: medicinal chemistry perspective. Med Drug Discov, 2019; 2:100009-11.

Montana M, Mathias F, Terme T, Vanelle P. Antitumoral activity of quinoxaline derivatives: a systematic review. Eur J Med Chem, 2019; 163:136-47.

Mosoarca EM, Pantenburg I, Tudose R, Meyer G, Popa NC, Han A, Alexandrova R, Kalfin R, Linert W, Costisor O. Synthesis, structure and cytotoxic activity of mixed-valent $\mathrm{Cu}(\mathrm{I}) / \mathrm{Cu}(\mathrm{II})$ salt containing a pyrazolone derivative as a ligand. Inorg Chim Acta, 2011; 370:460-68.

Mu LM, Ju RJ, Liu R, Bu YZ, Zhang JY, Li XQ, Zeng F, Lu WL. Dual-functional drug liposomes in the treatment of resistant cancers. Adv Drug Deliv Rev, 2017; 115:46-6.

Narayana Rao DV, Raghavendra Guru Prasad A, Spoorthy YN, Raghunatha Rao D, Ravindranath L K. In vitro microbiological evaluation of novel bis pyrazolones. Ann Pharmacol Franç, 2014; 72:101-6.

Parmar N, Teraiya S, Patel R, Barad H, Jajda H, Thakkar V. Synthesis, antimicrobial and antioxidant activities of some 5-pyrazolone based Schiff bases. J Saudi Chem Soc, 2015; 19:36-1.

Paulpandiyan R, Raman N. DNA binding propensity and nuclease efficacy of bio sensitive Schiff base complexes containing pyrazolone moiety: synthesis and characterization. J Mol Struct, 2016; 1125:374-82.

Pettinari R, Marchetti F, Di Nicola C, Pettinari C, Galindo A, Petrelli R, Cappellacci L, Cuccioloni M, Bonfili L, Eleuteri AM, Guedes da Silva MFC, Pombeiro AJL. Ligand design for N,O- or N, N-pyrazolonebased hydrazones ruthenium(II)-arene complexes and investigation of their anticancer activity. Inorg Chem, 2018; 57:14123-3.

Pettinari R, Marchetti F, Pettinari C, Petrini A, Scopelliti R, Clavel CM, Dyson PJ. Synthesis, structure, and antiproliferative activity of ruthenium(II) arene complexes with N,O-chelating pyrazolone-based $\beta$-Ketoamine ligands. Inorg Chem, 2014; 53:13105-11.

Rashid H, Xu Y, Muhammad Y, Wang L, Jiang J. Research advances on anticancer activities of matrine and its derivatives: an updated overview. Eur J Med Chem, 2019; 161:205-38.

Rizk HF, Ibrahim SA, El-Borai MA. Synthesis, dyeing performance on polyester fiber and antimicrobial studies of some novel 
pyrazolotriazine and pyrazolyl pyrazolone azo dyes. Arab J Chem, 2017; 10:3303-9.

Saad FA, El-Metwaly NM, Farghaly TA, El-Ghalban MG, AlHazmi GA, Saleh KA, Alfaifi MY. Illustration for series of new metal ion complexes extracted from pyrazolone derivative, spectral, thermal, QSAR, DFT/B3LYP, docking, and antitumor investigations. J Mol Liq, 2016; 229:614-27.

Saidachary G, Veera Prasad K, Divya D, Singh A, Ramesh U, Sridhar B, China Raju B. Convenient one-pot synthesis, anti-mycobacterial and anticancer activities of novel benzoxepinoisoxazolones and pyrazolones. Eur J Med Chem, 2014; 76:460-69.

Singh N, Krishnakumar S, Kanwar RK, Cheung CHA, Kanwar JR. Clinical aspects for surviving: a crucial molecule for targeting drugresistant cancers. Drug Discov Today, 2015; 20:578-87.

Sivakumar KK, Rajasekaran A, Senthilkumar P, Wattamwar PP. Conventional and microwave-assisted synthesis of pyrazolone Mannich bases possessing anti-inflammatory, analgesic, ulcerogenic effect and antimicrobial properties. Bioorg Med Chem Lett, 2014; 24:2940-44.

Stornaiuolo M, La Regina G, Passacantilli S, Grassia G, Coluccia A, La Pietra V, Giustiniano M, Cassese H, Di Maro S, Brancaccio D, Taliani S. Structure-based lead optimization and biological evaluation of BAX direct activators as novel potential anticancer agents. J Med Chem, 2015; 58:2135-48.

Tang, Y, Rong, X, Hu, W, Li, G, Yang, X, Yang, J, Xu, P, Luo, J. Effect of edaravone on radiation-induced brain necrosis in patients with nasopharyngeal carcinoma after radiotherapy: a randomized controlled trial. J Neurooncol, 2014, 120:441-47

Tok F, Koçyiğit-Kaymakçıŏlu B, Nurpelin Sağlık B, Levent S, Özkay Y, Asım Kaplancıklı Z. Synthesis and biological evaluation of new pyrazolone schiff bases as monoamine oxidase and cholinesterase inhibitors. Bioorg Chem, 2019; 84:41-50.

Tripathy R, Ghose A, Singh J, Bacon ER, Angeles TS, Yang SX, Albom MS, Aimone LD, Herman JL, Mallamo JP. 1,2,3-Thiadiazole substituted pyrazolones as potent KDR/VEGFR-2 kinase inhibitors. Bioorg Med Chem Lett, 2007; 17:1793-98.

Tripathy R, McHugh RJ, Ghose AK, Ott GR, Angeles TS, Albom MS, Huang Z, Aimone LD, Cheng M, Dorsey BD. Pyrazolonebased anaplastic lymphoma kinase (ALK) inhibitors: control of selectivity by a benzyloxy group. Bioorg Med Chem Lett, 2011; 21:7261-64.

Tüzün, B. Investigation of pyrazoly derivatives schiff base ligands and their metal complexes used as anti-cancer drug. Spectrochim Acta A Mol Biomol Spectrosc, 2019, 15; 11763-67

Vyas KM, Jadeja RN, Patel D, Devkar RV, Gupta VK. A new pyrazolone based ternary $\mathrm{Cu}$ (II) complex: Synthesis, characterization, crystal structure, DNA binding, protein binding and anti-cancer activity towards A549 human lung carcinoma cells with a minimum cytotoxicity to non-cancerous cells. Polyhedron, 2013, 28; 65:262-74.

Vyas KM, Jadeja RN, Patel D, Devkar RV, Gupta VK. Effect of ligand substitution in pyrazolone based binary and ternary $\mathrm{Cu}$ (II) complexes on DNA binding, protein binding and anti-cancer activity on A549 lung carcinoma cell lines. Polyhedron, 2014; 80:20-33.

Weast RC. Hand book of chemistry and physics. CRC Press Inc, Cleveland, Ohio, p 58, 1977.

Wiley R, Wiley P. Pyrazolones, pyrazolidones and derivatives: the chemistry of heterocyclic compounds. 20th edition, A Weissberger Interscience Publishers, New York, NY, pp 1-12, 1964.

Yousuf S, Khan KM, Salar U, Chigurupati, S, Muhammad MT, Wadood A, Aldubayan M, Vijayan V, Riaz M, Perveen S. 2'-Aryl and 4 '-arylidene substituted pyrazolones: as potential $\alpha$-amylase inhibitors. Eur J Med Chem, 2018; 159:47-58.

Zhang Y, Zhang L, Liu L, Guo J, Wu D, Xu G, Wang X, Jia D. Anticancer activity, structure, and theoretical calculation of N-(1-phenyl3-methyl-4-propyl-pyrazolone-5)-salicylidene hydrazone and it's copper(II) complex. Inorganica Chim Acta, 2010; 363:289-93.

Zhao J, Zhang L, Li J, Wu T, Wang M, Xu G, Zhang F, Liu L, Yang J, Sun S. A novel pyrazolone-based derivative induces apoptosis in human esophageal cells via reactive oxygen species (ROS) generation and caspase-dependent mitochondria-mediated pathway. Chem Biol Interact $2015 ; 231: 1-9$

Zhuang C, Guan X, Ma H, Cong H, Zhang W, Miao Z. Small molecule-drug conjugates: a novel strategy for cancer-targeted treatment Eur J Med Chem, 2019; 163:883-95.

Zong Z, Wei X, Yan X, Fan Y.Crystal structures and anticancer activities of five novel pyrazolone-enamine transition metal complexes with 4-benzoyl-3-methyl-1-phenyl-2-pyrazolin-5-one. J Mol Struct, 2018; 1171:333-39.

How to cite this article:

Adhikari S, Singh M, Sharma P, Arora S. Pyrazolones as potential anticancer scaffold: Recent trends and future perspectives. J Appl Pharm Sci, 2021; 11 (Supp 1):026-037. 